\title{
Research Letter \\ Fire Resistance of Wood Impregnated with Soluble Alkaline Silicates
}

\author{
Carlos Alberto Giudice ${ }^{1,2}$ and Andrea Marisa Pereyra ${ }^{1,2}$ \\ ${ }^{1}$ Centro de Investigación y Desarrollo en Tecnología de Pinturas (CIDEPINT), calle 52 e/121 y 122, La Plata 1900, Argentina \\ ${ }^{2}$ Universidad Tecnológica Nacional (UTN), calle 60 y 124, La Plata 1900, Argentina
}

Correspondence should be addressed to Carlos Alberto Giudice, cagiudice@yahoo.com

Received 23 September 2007; Accepted 7 November 2007

Recommended by Luigi Nicolais

The aim of this paper is to determine the fire performance of wood panels (Araucaria angustifolia) impregnated with soluble alkaline silicates. Commercial silicates based on sodium and potassium with 2.5/1.0 and 3.0/1.0 silica/alkali molar ratios were selected; solutions and glasses were previously characterized. Experimental panels were tested in a limiting oxygen chamber and in a twofoot tunnel. Results displayed a high fire-retardant efficiency using some soluble silicates.

Copyright (c) 2007 C. A. Giudice and A. M. Pereyra. This is an open access article distributed under the Creative Commons Attribution License, which permits unrestricted use, distribution, and reproduction in any medium, provided the original work is properly cited.

\section{INTRODUCTION}

Woods and their subproducts are materials of wide use in the construction in spite of being highly combustible [1-3]. Propagation rate is higher at the beginning of the conflagration due to nonexistence of restrictive barriers; when charring takes place [4-7], the mentioned rate decreases since the protective effect of the carbonaceous layer reduces the transmission of heat and also avoids the oxygen access at the interface combustible substrate/air.

The aim of this research is to determine the relative behavior to fire of Araucaria angustifolia impregnated with soluble alkaline silicates (water glasses) in relation to natural panels (without any treatment).

\section{SOLUBLE SILICATES CHARACTERIZATION}

Soluble silicates dissolve in water forming viscous solutions with a high-stability degree. They have variable composition; therefore, it is convenient to define them by silica/alkaline oxide in weight or mole ratio $[8,9]$. Water glasses selected were based on sodium and potassium ions with 2.5/1.0 and 3.0/1.0 silica/alkali mole ratios. Visual observations of the solutions extended on glass allowed to infer that with more silica, content showed films with a higher drying and curing rates; besides, those of smaller level of silica, once dried and cured in laboratory conditions, displayed a higher dissolution rate.
Expansion values indicate, in the first intervals of temperature, an almost lineal increase; whereas a faster rise was noted at higher temperatures. The volumetric coefficients, in total correspondence with those of lineal dilation, showed a reduced expansion inclusive at temperatures between 25 and $800{ }^{\circ} \mathrm{C}$ (approx. those registered in a fire): the values ranged from 3.6 to $3.8 \%$. This would favor the stability and resistance of the treated wood during a conflagration.

\section{IMPREGNATION PROCESS}

Panels were prepared from Araucaria angustifolia, a porous wood of low density $\left(0.497 \mathrm{~g} \cdot \mathrm{cm}^{-3}\right)$ and also easily penetrable. With the purpose of achieving a good impregnation, panels remained in laboratory until reaching humidity levels between 15 and $18 \%$. Surface tension was adjusted in all the solutions with sodium dodecyl sulphate to $38 \mathrm{dyne} \cdot \mathrm{cm}^{-1}$.

Operative conditions in the vertical pressure vessel were $20^{\circ} \mathrm{C}$ during the whole of the process and $400 \mathrm{~mm} \mathrm{Hg}$ for 30 minutes to evacuate the air and the water vapor in the panel's cells. In the first series, the impregnant solution was added without decreasing the vacuum level until reaching the $1 / 3 \mathrm{wood} /$ solution ratio in volume. Later on, the pressure was gradually increased until $6.5 \mathrm{Kg} \cdot \mathrm{cm}^{-2}$; this stage extended during 120 minutes. The selected wood/solution ratio assured in all the cases that panels were fully submerged. 
Finally, panels were extracted after lowering the pressure, rinsed, and air-dried in laboratory $\left(20-22{ }^{\circ} \mathrm{C}\right.$; $50-55 \%$ relative humidity) until constant weight.

In a second series, panels after having executed the mentioned stages were placed in a forced draft oven for 24 hours at $90{ }^{\circ} \mathrm{C}$ to facilitate silicates polymerization.

In the third series, after finishing the procedure in vessel indicated for the first ones, panels were impregnated with a $10 \%$ alcoholic solution of dibutyl amine phosphate; this salt hydrolyzes slowly to liberate phosphoric acid in contact with an alkaline solution. Panels that took off from vessel were exposed in laboratory until reaching constant weight.

In the fourth series, panels were treated in a similar way to the aforementioned but including a final heating for 24 hours at $90^{\circ} \mathrm{C}$ similar to that carried out in the second series.

Group A corresponds to the air-dried panels whereas Group B also includes the air-dried panels but with a later aging in a humidity and temperature controlled chamber (HTCC) at $100 \%$ and $35^{\circ} \mathrm{C}$ for 500 hours, in both cases before beginning the tests.

\section{FIRE TESTS}

One of the tests carried out on panels was the two-foot tunnel $[10,11]$, according to ASTM (Pa, USA). Flame spread index (FSI) was computed using the equation FSI $=(\mathrm{Ls}-$ Lo)/(Lb - Lo), where Ls, Lo, and Lb are, respectively, the average of the three flame-advance readings on experimental panel, on asbestos-cement board (zero flame-spread), and on natural wood panel. Panel consumption (PC), after-flaming time (AFT), and after-glow time (AGT) were also determined. Another test was the limiting oxygen index (LOI), according to ASTM [12], the flow rate was $4.0 \mathrm{~cm} \cdot \mathrm{s}^{-1}$. Both tests were done in triplicate.

\section{RESULTS AND CONCLUSIONS}

\subsection{Retentions and penetrations}

The retentions were gravimetrically calculated. $W_{f}$ is the final weight of the panel impregnated, air-dried until constant weight, and expressed by volume unit. On the other hand, $W_{i}$ is the initial weight of the panel without impregnating, also dried to the air up to constant weight and expressed by volume unit. The retention is the difference between $W_{f}$ and $W_{i}$. The retention varied narrowly from 128 to $136 \mathrm{Kg} \cdot \mathrm{m}^{-3}$; the average value was $131 \mathrm{Kg} \cdot \mathrm{m}^{-3}$.

Concerning the penetrations, these were carried out through microscopic observations on panel's cuts; these attained in the $90 \%$ of the cases, the whole of panel thickness, while in the $10 \%$ remaining, these were slightly irregular; Figures 1 and 2 show that final average density was $0.557 \mathrm{~g} \cdot \mathrm{cm}^{-3}$.

\subsection{Fire performance}

\section{Group A}

Average results in two-foot tunnel are displayed in Table 1. FSI indicates an improved performance of the all-treated pan- els in relation with the natural ones as well as a marked difference among the performance of the designed treatments. That is, panels of the first series A.2/A.5 showed a significant decrease of the FSI with regard to A.1 (FSI = 1.00, which implies a flame advance along the whole of the panel length). Panels A.2/A.5 showed FSI values between 0.35 and 0.33 , that is, 196 and $185 \mathrm{~mm}$, respectively, beyond the advance registered on the reference panel (the average value was $50 \mathrm{~mm}$ ). Regarding the efficiency of the impregnants of this series, no sensitive difference of behavior among them was noted (silica/alkali ratio and alkaline-oxide type). Values of $P C, A F T$, and $A G T$ corroborated the conclusions reached when analyzing the FSI.

Samples of the second series with later heating slightly improved the performance of those of first ones. Formulation variables would not have exerted in this series a significant influence on performance as well. The mentioned tendency was also observed in the third and fourth series with regard to the previous ones. In consequence, panels of the fourth series displayed the best efficiency (the smallest values of FSI and PC, with null AFT and AGT). The A.17 showed an FSI = 0.20 ( $112 \mathrm{~mm}$ of net advance of flame), a PC of only $2.68 \%$, and null AFT and AGT. This efficiency of the treated Araucaria angustifolia is similar to those of dense woods: low FSI, minimum PC, and null AFT and AGT.

Heating and/or application of the catalyst would have favored by dehydration the formation of polymeric silicic acids of high molecular weight silanol condensation with silanol groups $(\equiv \mathrm{SiOH})$ or alcohoxides ( $\equiv \mathrm{SiOR})$ and in consequence glasses of elevated melting point and specific heat capacity, with the aforementioned reduced thermal expansion, would be the responsible for the improved performance against the action of fire.

Panels in the LOI chamber also showed an increasing effectiveness, starting from those natural woods to the fourth series, that is, no treated panels displayed an LOI of $16 \%$. (The last one allows to classify them as easily combustible since the mentioned value is sensibly inferior to the percentage level of oxygen in the air.) The treated panels exhibited in all cases values higher than $28 \%$ which are accepted as experimental minimum limit for this test. The latest allows classifying all treated samples as self-extinguishing [13]; the A.16 and A.17 exhibited the highest LOI values, $40 \%$ for the first case and $42 \%$ for the second one.

\section{Group B}

Average results are also included in Table 1 . The series B.2/B.5, although exhibited in general a better effectiveness than the panel B.1, showed in two-foot tunnel and LOI chamber a performance sensibly decreased with regard to A.2/A.5: higher values of FSI, PC, AFT, and AGT in the first test and less oxygen requirement in the second one.

Silicates solubility (particularly those of lower silica/alkali ratio) justifies the quoted behavior since panels were aged previously in the HTCC $[14,15]$. Partial lixiviation of the soluble silicates was verified determining the retention and penetration values; although the first ones diminished as maximum $10 \%$ in panels for LOI test and $6 \%$ for those used in 

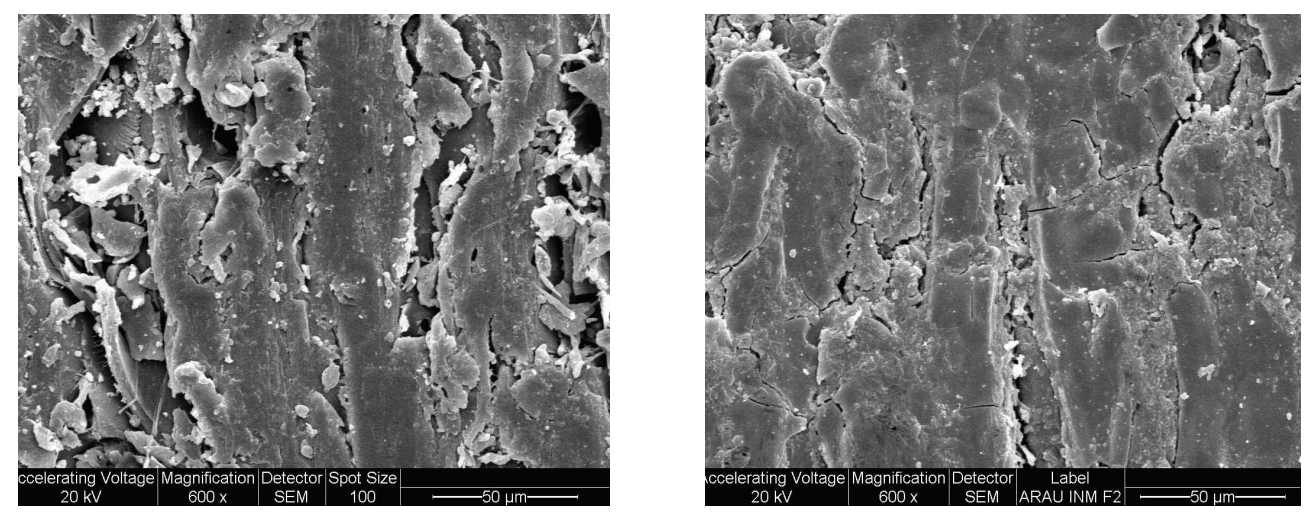

FIGURE 1: Morphology by SEM of the Araucaria angustifolia: left, original panel; right, impregnated panel.

TABLE 1: Results. (A corresponds to the air-dried panels; B includes the air-dried panels; and a later aging in a humidity and temperature controlled chamber.)

\begin{tabular}{|c|c|c|c|c|c|c|}
\hline & \multirow{2}{*}{ Sample } & \multicolumn{4}{|c|}{ Two-foot tunnel } & \multirow[b]{2}{*}{ LOI, \% } \\
\hline & & FSI & $\mathrm{PC}, \%$ & AFT, seg & AGT, seg & \\
\hline \multirow{17}{*}{ A } & 1. No treatment; no silicates & 1.00 & 7.18 & 2 & 1 & 16 \\
\hline & 2. No treatment; $\mathrm{SiO}_{2} / \mathrm{Na}_{2} \mathrm{O}: 2.5 / 1.0$ & 0.35 & 3.31 & 1 & 0 & 34 \\
\hline & 3. No treatment; $\mathrm{SiO}_{2} / \mathrm{Na}_{2} \mathrm{O}: 3.0 / 1.0$ & 0.33 & 3.37 & 1 & 0 & 34 \\
\hline & 4. No treatment; $\mathrm{SiO}_{2} / \mathrm{K}_{2} \mathrm{O}: 2.5 / 1.0$ & 0.33 & 3.17 & 1 & 0 & 35 \\
\hline & 5. No treatment; $\mathrm{SiO}_{2} / \mathrm{K}_{2} \mathrm{O}: 3.0 / 1.0$ & 0.34 & 3.13 & 1 & 0 & 35 \\
\hline & 6. $90^{\circ} \mathrm{C}, 24 \mathrm{~h} ; \mathrm{SiO}_{2} / \mathrm{Na}_{2} \mathrm{O}: 2.5 / 1.0$ & 0.31 & 3.17 & 1 & 0 & 33 \\
\hline & 7. $90^{\circ} \mathrm{C}, 24 \mathrm{~h} ; \mathrm{SiO}_{2} / \mathrm{Na}_{2} \mathrm{O}: 3.0 / 1.0$ & 0.29 & 3.28 & 1 & 0 & 34 \\
\hline & 8. $90^{\circ} \mathrm{C}, 24 \mathrm{~h} ; \mathrm{SiO}_{2} / \mathrm{K}_{2} \mathrm{O}: 2.5 / 1.0$ & 0.29 & 3.21 & 1 & 0 & 35 \\
\hline & 9. $90^{\circ} \mathrm{C}, 24 \mathrm{~h} ; \mathrm{SiO}_{2} / \mathrm{K}_{2} \mathrm{O}: 3.0 / 1.0$ & 0.28 & 3.13 & 1 & 0 & 36 \\
\hline & 10. Catalyst; $\mathrm{SiO}_{2} / \mathrm{Na}_{2} \mathrm{O}: 2.5 / 1.0$ & 0.29 & 3.23 & 1 & 0 & 34 \\
\hline & 11. Catalyst; $\mathrm{SiO}_{2} / \mathrm{Na}_{2} \mathrm{O}: 3.0 / 1.0$ & 0.28 & 3.22 & 1 & 0 & 34 \\
\hline & 12. Catalyst; $\mathrm{SiO}_{2} / \mathrm{K}_{2} \mathrm{O}: 2.5 / 1.0$ & 0.28 & 3.11 & 1 & 0 & 37 \\
\hline & 13. Catalyst; $\mathrm{SiO}_{2} / \mathrm{K}_{2} \mathrm{O}: 3.0 / 1.0$ & 0.26 & 2.93 & 1 & 0 & 38 \\
\hline & 14. Catalyst; $90^{\circ} \mathrm{C}, 24 \mathrm{~h} ; \mathrm{SiO}_{2} / \mathrm{Na}_{2} \mathrm{O}: 2.5 / 1.0$ & 0.24 & 2.98 & 0 & 0 & 38 \\
\hline & 15. Catalyst; $90^{\circ} \mathrm{C}, 24 \mathrm{~h} ; \mathrm{SiO}_{2} / \mathrm{Na}_{2} \mathrm{O}: 3.0 / 1.0$ & 0.24 & 2.90 & 0 & 0 & 39 \\
\hline & 16. Catalyst; $90^{\circ} \mathrm{C}, 24 \mathrm{~h} ; \mathrm{SiO}_{2} / \mathrm{K}_{2} \mathrm{O}: 2.5 / 1.0$ & 0.22 & 2.83 & 0 & 0 & 40 \\
\hline & 17. Catalyst; $90^{\circ} \mathrm{C}, 24 \mathrm{~h} ; \mathrm{SiO}_{2} / \mathrm{K}_{2} \mathrm{O}: 3.0 / 1.0$ & 0.20 & 2.68 & 0 & 0 & 42 \\
\hline \multirow{17}{*}{ B } & 1. No treatment; no silicates & 1.00 & 7.22 & 2 & 1 & 17 \\
\hline & 2. No treatment; $\mathrm{SiO}_{2} / \mathrm{Na}_{2} \mathrm{O}: 2.5 / 1.0$ & 0.66 & 5.01 & 2 & 1 & 22 \\
\hline & 3. No treatment; $\mathrm{SiO}_{2} / \mathrm{Na}_{2} \mathrm{O}: 3.0 / 1.0$ & 0.61 & 4.82 & 2 & 1 & 24 \\
\hline & 4. No treatment; $\mathrm{SiO}_{2} / \mathrm{K}_{2} \mathrm{O}: 2.5 / 1.0$ & 0.65 & 4.91 & 2 & 1 & 22 \\
\hline & 5. No treatment; $\mathrm{SiO}_{2} / \mathrm{K}_{2} \mathrm{O}: 3.0 / 1.0$ & 0.56 & 4.61 & 2 & 1 & 25 \\
\hline & 6. $90^{\circ} \mathrm{C}, 24 \mathrm{~h} ; \mathrm{SiO}_{2} / \mathrm{Na}_{2} \mathrm{O}: 2.5 / 1.0$ & 0.52 & 4.17 & 2 & 1 & 25 \\
\hline & 7. $90^{\circ} \mathrm{C}, 24 \mathrm{~h} ; \mathrm{SiO}_{2} / \mathrm{Na}_{2} \mathrm{O}: 3.0 / 1.0$ & 0.48 & 4.28 & 2 & 1 & 26 \\
\hline & 8. $90^{\circ} \mathrm{C}, 24 \mathrm{~h} ; \mathrm{SiO}_{2} / \mathrm{K}_{2} \mathrm{O}: 2.5 / 1.0$ & 0.51 & 4.31 & 2 & 1 & 27 \\
\hline & 9. $90^{\circ} \mathrm{C}, 24 \mathrm{~h} ; \mathrm{SiO}_{2} / \mathrm{K}_{2} \mathrm{O}: 3.0 / 1.0$ & 0.46 & 4.21 & 2 & 1 & 27 \\
\hline & 10. Catalyst; $\mathrm{SiO}_{2} / \mathrm{Na}_{2} \mathrm{O}: 2.5 / 1.0$ & 0.32 & 3.38 & 1 & 0 & 35 \\
\hline & 11. Catalyst; $\mathrm{SiO}_{2} / \mathrm{Na}_{2} \mathrm{O}: 3.0 / 1.0$ & 0.31 & 3.32 & 1 & 0 & 35 \\
\hline & 12. Catalyst; $\mathrm{SiO}_{2} / \mathrm{K}_{2} \mathrm{O}: 2.5 / 1.0$ & 0.30 & 3.07 & 1 & 0 & 37 \\
\hline & 13. Catalyst; $\mathrm{SiO}_{2} / \mathrm{K}_{2} \mathrm{O}: 3.0 / 1.0$ & 0.28 & 2.97 & 0 & 0 & 39 \\
\hline & 14. Catalyst; $90^{\circ} \mathrm{C}, 24 \mathrm{~h} ; \mathrm{SiO}_{2} / \mathrm{Na}_{2} \mathrm{O}: 2.5 / 1.0$ & 0.26 & 3.01 & 0 & 0 & 39 \\
\hline & 15. Catalyst; $90^{\circ} \mathrm{C}, 24 \mathrm{~h} ; \mathrm{SiO}_{2} / \mathrm{Na}_{2} \mathrm{O}: 3.0 / 1.0$ & 0.26 & 2.94 & 0 & 0 & 40 \\
\hline & 16. Catalyst; $90^{\circ} \mathrm{C}, 24 \mathrm{~h} ; \mathrm{SiO}_{2} / \mathrm{K}_{2} \mathrm{O}: 2.5 / 1.0$ & 0.24 & 2.87 & 0 & 0 & 42 \\
\hline & 17. Catalyst; $90^{\circ} \mathrm{C}, 24 \mathrm{~h} ; \mathrm{SiO}_{2} / \mathrm{K}_{2} \mathrm{O}: 3.0 / 1.0$ & 0.22 & 2.74 & 0 & 0 & 43 \\
\hline
\end{tabular}


$\mathrm{E}: \backslash 2007 \backslash$ AINME1.spc

Label A: AINME1

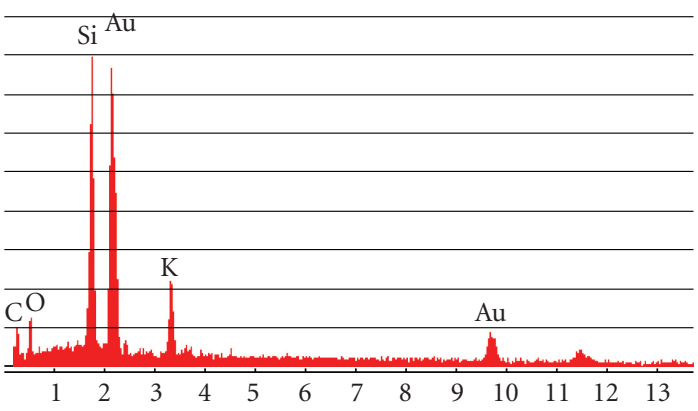

FIGURE 2: EDAX of an impregnated panel for testing in two-foot tunnel: $\mathrm{Si}$ at $5 \mathrm{~mm}$ depth.

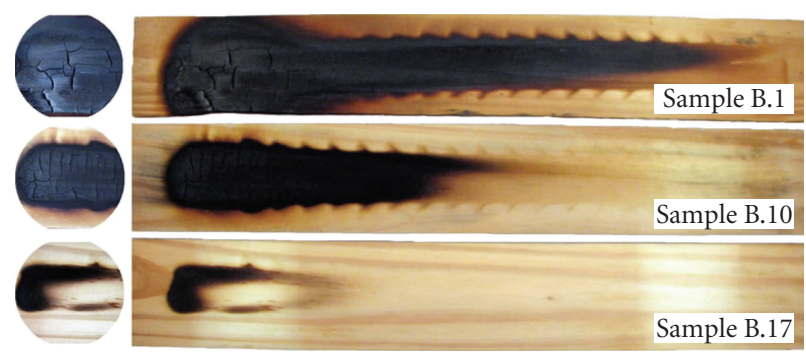

Figure 3: Wood panels tested in two-foot tunnel.

two-foot tunnel, the distribution in depth observed by microscopy indicated a very reduced presence on the surface (up to $1 \mathrm{~mm}$, according to the impregnant-material type) and a growing profile toward the interior (starting from 2 or $3 \mathrm{~mm}$, a similar homogeneous retention to the existent in the core of the sample was detected).

On the other hand, B.6/B.9 panels showed an improvement with regard to the previous series; however the treatment at $90^{\circ} \mathrm{C}$ for 24 hours was insufficient to drive the silicates to insolubility or to reduced dissolution kinetics since the effectiveness of the A.6/A.9 panels was markedly superior.

Regarding B.10/B.13, an improved behavior was observed with regard to the previous one; however, these results are very similar to those registered for the panels A.10/A.13, as shown in Figure 3.

Results permit to conclude that catalyst drove to the formation of insoluble polymeric silicates or else of reduced distilled-water dissolution rate. As a consequence, impregnant material kept fixed inside porous after exposition in HTCC (the retention and penetration values corroborated what was quoted before).

Concerning B.14/B.17, results confirmed the mentioned conclusions; chemical reactions for forming the polymeric silicic acid drove to the best behavior, as shown in Figure 3.

The improved performance of the whole impregnated panels in relation with those without any treatment can be explained considering that the first ones had a higher content of noncombustible material in their composition (alkaline silicates or polymeric silicic acids) than the second ones, that is, the treated woods diminished the percentage level of organic material and either eliminated or sensitively decreased the presence of oxygen inside the porous.

Finally, a significant advantage of the alkaline silicates for the treatment of woods, beyond the aforementioned ones such as the high-retardant efficiency and the minimum thermal expansion: their reduced generation of smoke during the conflagration without any toxicity for the human beings; their low cost constitutes another excellent factor. Among the most essential disadvantages, must be cited the high alkalinity of the solutions that demands a special care for their manipulation.

\section{REFERENCES}

[1] R. Athey, et al., European Coatings Journal, vol. 10, p. 428, 1999.

[2] C. Holmes, "Effect of fire-retardant treatments on performance properties of wood," in Wood Technology: Chemical Aspects, I. S. Goldstein, Ed., vol. 43 of ACS Symposium Series, p. 82, American Chemical Society, Washington, DC, USA, 1977.

[3] P. Sargent, "Multi-layer paint: the fire problem," Pigment \& Resin Technology, vol. 27, no. 6, pp. 361-363, 1998.

[4] R. Koslowsky, in Fire Retardant Materials, A. R. Horrocks and D. Price, Eds., p. 293, CRC Press, Cardiff, UK, 2004.

[5] A. Factor, in Fire and Polymers, G. Nelson , Ed., ACS Symposium Series, p. 274, American Chemical Society, Washington, DC, USA, 1990.

[6] C. Wilkie, in Fire and Polymers, G. Nelson, Ed., ACS Symposium Series, p. 178, American Chemical Society, Washington, DC, USA, 1990.

[7] D. Drysdale, in Fire Retardant Materials, A. R. Horrocks and D. Price, Eds., p. 378, CRC Press, Cardiff, UK, 2004.

[8] M.-S. Tsai, C.-H. Yang, and P.-Y. Huang, "Effects of seeds concentration on the formation of colloidal silica," Materials Science and Engineering B, vol. 123, no. 3, pp. 238-241, 2005.

[9] M.-S. Tsai, P. Y. Huang, and W.-C. Wu, "The study of formation process of colloidal silica," Materials Research Bulletin, vol. 40, no. 9, pp. 1609-1616, 2005.

[10] M. Caciolai, Anticorrosione, vol. 7, no. 25, p. 29, 1999.

[11] R. Shaw, Journal of the Oil and Colour Chemists' Association, vol. 72, no. 5, p. 176, 1999.

[12] R. Hindersinn, in Fire and Polymers, G. Nelson, Ed., ACS Symposium Series, p. 87, American Chemical Society, Washington, DC, USA, 1990.

[13] L. Wake, et al., Journal of Coatings Technology, vol. 67, no. 844, p. 29, 1995.

[14] M. Dietzel, "Dissolution of silicates and the stability of polysilicic acid," Geochimica et Cosmochimica Acta, vol. 64, no. 19, pp. 3275-3281, 2000.

[15] I. Papisova, K. I. Bolyachevskaya, A. A. Litmanovich, V. N. Matveenko, and I. L. Volchkova, "Structural effects in matrix polycondensation of silicic acid," European Polymer Journal, vol. 35, no. 11, pp. 2087-2094, 1999. 

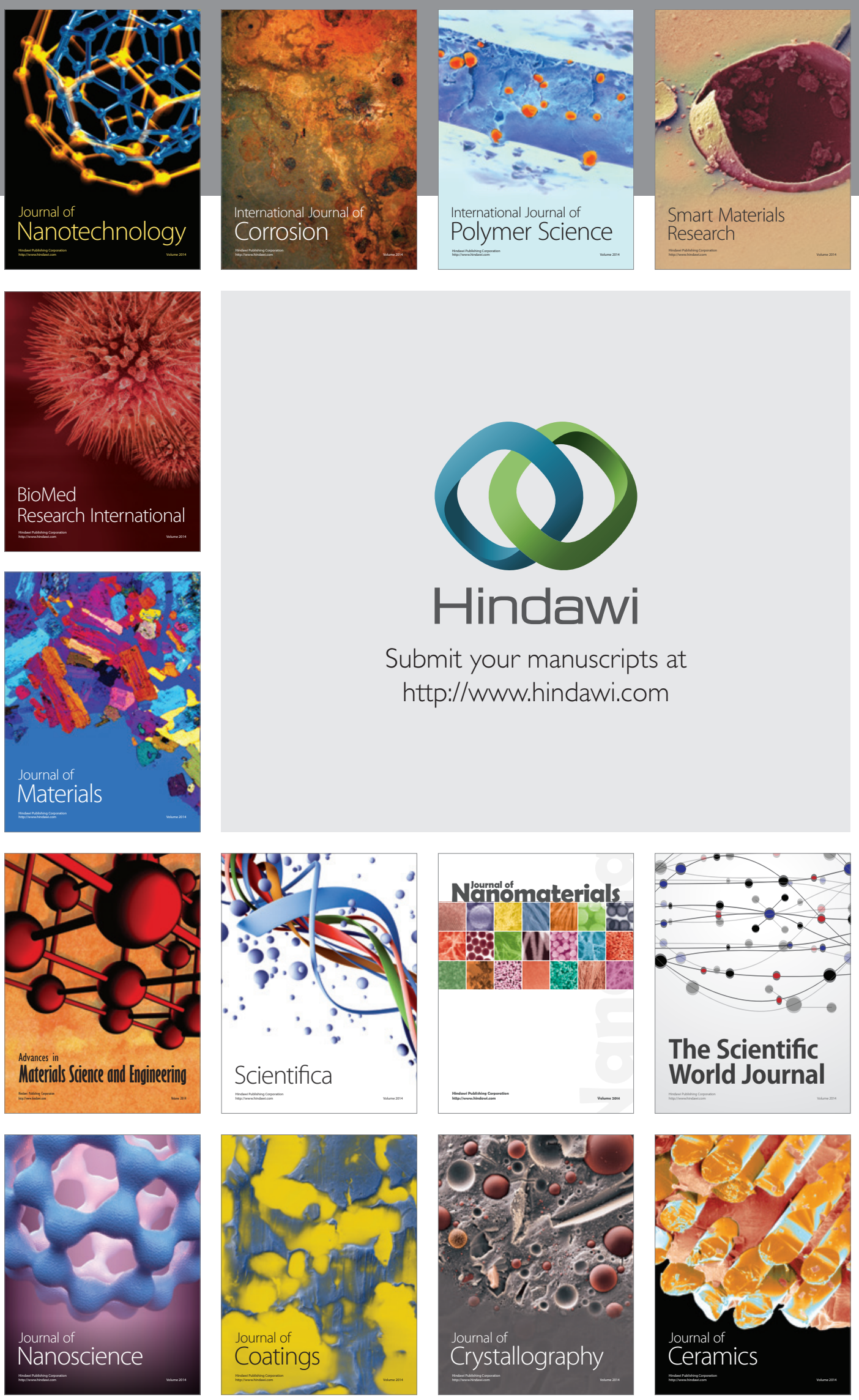

The Scientific World Journal

Submit your manuscripts at

http://www.hindawi.com

\section{World Journal}

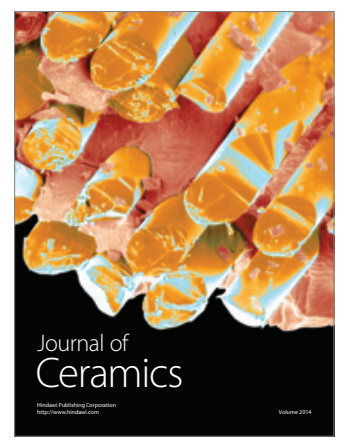

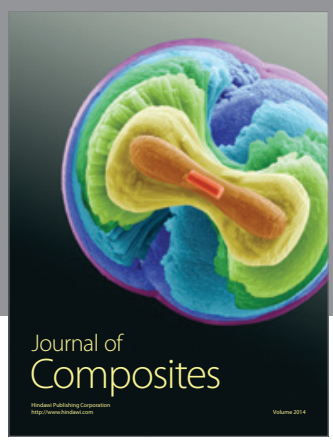
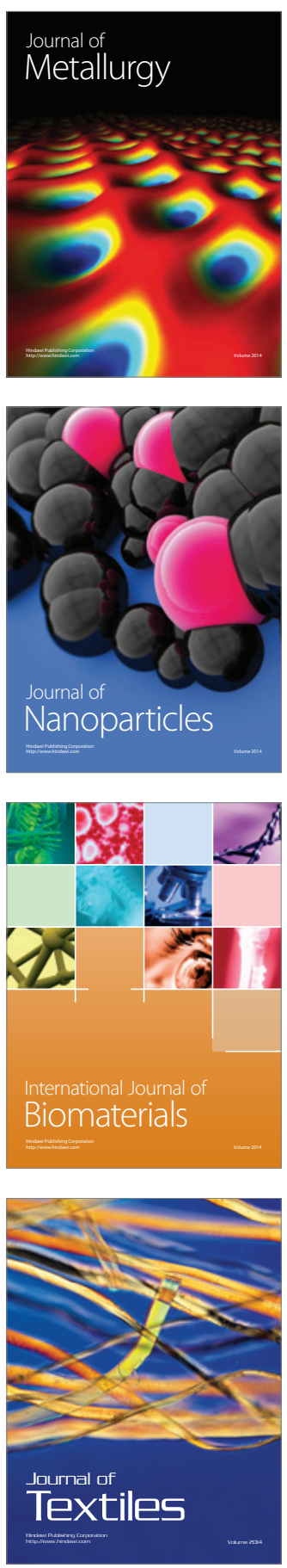